\title{
The Funtana Morimenta Ichnosite (Sardinia, Italy): a Potential Geotourist Attraction
}

\author{
Daniel Zoboli ${ }^{1}$ (D) Gian Luigi Pillola ${ }^{1}$ (D) \\ Received: 13 August 2020 / Accepted: 11 March 2021 / Published online: 20 March 2021 \\ (C) The Author(s) 2021
}

\begin{abstract}
The late Middle Pleistocene ichnosite of Funtana Morimenta (Gonnesa, Italy) provides a relevant scientific and didactic interest. In this site, tracks of megacerine deer and dwarf mammoths of the Ice Age are well-preserved and visible in situ. The geosite has also historic importance, and it has been mentioned since the beginning of the nineteenth century for the sedimentological features and its palaeontological content. For these reasons, the Funtana Morimenta ichnosite would represent an efficient tool for developing educational goals, such as teaching activities or field trips. Unfortunately, in the last years, it has shown significant deterioration because its sedimentological features (poorly cemented aeolian sandstone) made it susceptible to weathering. For this site to be available for future generations, great attention should be posed to its safeguard and avoid the permanent disappearance of what is currently a full-fledged natural and scientific resource. The conservation actions herein proposed will provide several benefits: they are meant to (i) valorize the aeolian deposits and the visible ichnofossils; (ii) show visitors, tourists, or students the geo-palaeontological richness of the territory; (iii) encourage tourists to explore the other numerous geosites spread in the island of Sardinia; and (iv) allow private entrepreneurs or local public administrations to develop economic opportunities.
\end{abstract}

Keywords Geoconservation - Geological heritage · Geotourism · Protection and promotion · Socio-economic development . Sardinia

\section{Introduction}

Geosites provide a useful and very important contribution to the understanding of the geological history of a given area and have exceptional importance as regards scientific, cultural, and recreational aspects. These represent the geodiversity, understood as the set of distinctive geological, geomorphological, pedological, hydrological, sedimentological, and palaeontological characteristics of an area. In the last decades, geotourism is becoming increasingly popular as initiatives within geoparks suggest. This "cultural tourism" has the main purpose of promoting the history, culture, and traditions of a territory, contributing to the well-being of local communities (Dowling 2011).

Daniel Zoboli

danielc.zoboli@unica.it

1 Dipartimento di Scienze Chimiche e Geologiche, Univ. Cagliari, Cittadella Universitaria, SS 554, 09042 Monserrato, CA, Italy
As concerns geosciences, palaeontology is probably one of the most easily suitable disciplines to be divulged to the general public and can provide the starting point for initiatives aimed at the protection and divulgation of the geological heritage of a determinate territory. The palaeontological heritage is the whole of body fossils or ichnofossils (e.g., tracks ad trackways) that have been reported in the geological record and which have been assigned a scientific and educational value. The enhancement of geo-palaeontological heritage aims to promote protection and preservation, disclosing scientific data for use and enjoyment of the whole society, bringing this discipline to the general public (Henriques and Pena dos Reis 2015; Berrocal-Casero et al. 2018; Meléndez 2018). For these reasons, governments should protect and valorize the geo-palaeontological sites as it occurs to other tourist attractions (Melinte-Dobrinescu et al. 2017; Audije-Gil et al. 2018; Cobos and Alcalá 2018; Cobos et al. 2020; Vasconcelos et al. 2020). Probably, the most suitable and relatively common type of geo-palaeontological sites used as tourist attractions is the ichnosites. Indeed, numerous spectacular palaeontological sites with dinosaurs or other vertebrate tracks 
and trackways are currently used for this purpose in a great number of localities around the world (Arzarello et al. 2000; Berrocal-Casero et al. 2018; Cobos et al. 2020; Francischini et al. 2020).

In the last decades, the palaeontology of vertebrates of Sardinia has had a significant development that has led to a better knowledge of endemic mammals and evolution in insular ecosystems during Neogene (e.g., Abbazzi et al. 2008; Zoboli and Pillola 2017a; Mennecart et al. 2017, 2019) and Quaternary (e.g., Abbazzi et al. 2004; Palombo et al. 2006; Palombo 2009; Zoboli et al. 2016, 2019; Zoboli and Caddeo
2016; Zoboli and Pillola 2016, 2017b; Angelone et al. 2018). Besides, a series of research concerning tetrapod ichnology of Sardinia have been published (Fanelli et al. 2007; Marchetti et al. 2018, 2020; Pillola et al. 2020). In particular, these latest works highlighted how Pleistocene ichnosites are relatively numerous along the western coast of Sardinia and providing useful data for palaeoenvironmental reconstructions.

Among the numerous ichnosites reported in the Pleistocene of Sardinia, the geosite of Funtana Morimenta (Fig. 1) has recently provided a series of useful and interesting data that allowed recognition of new ichnotaxa in the ichnofossil record a
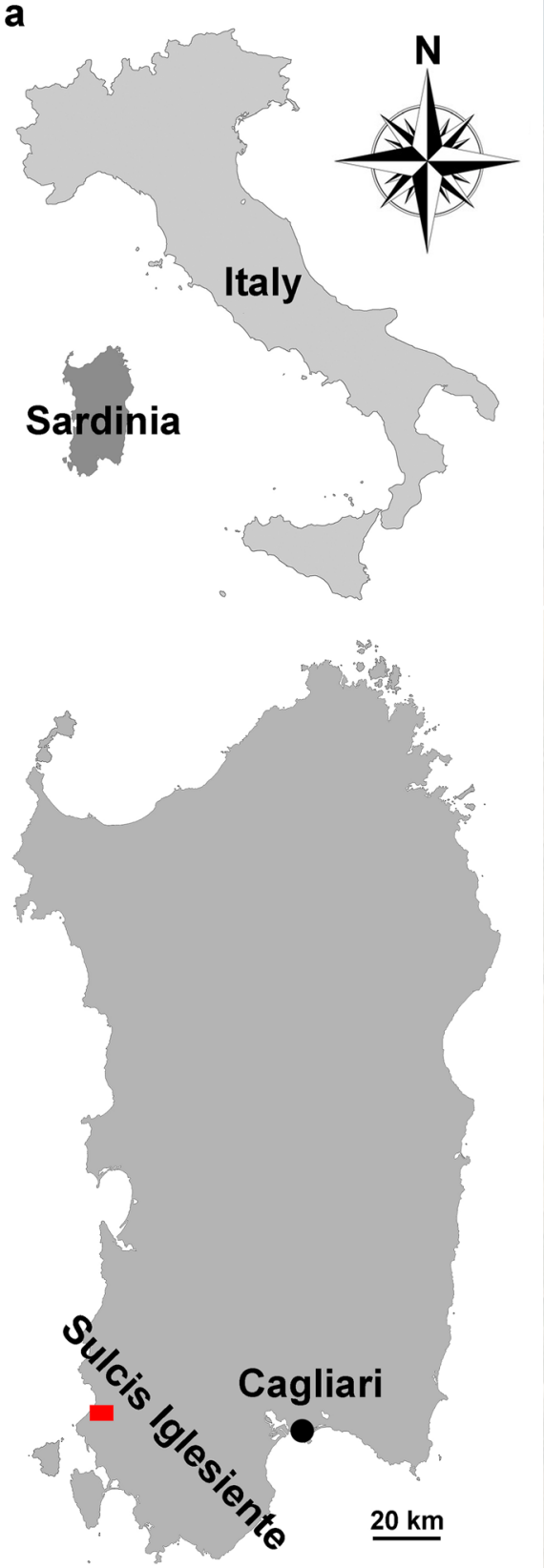
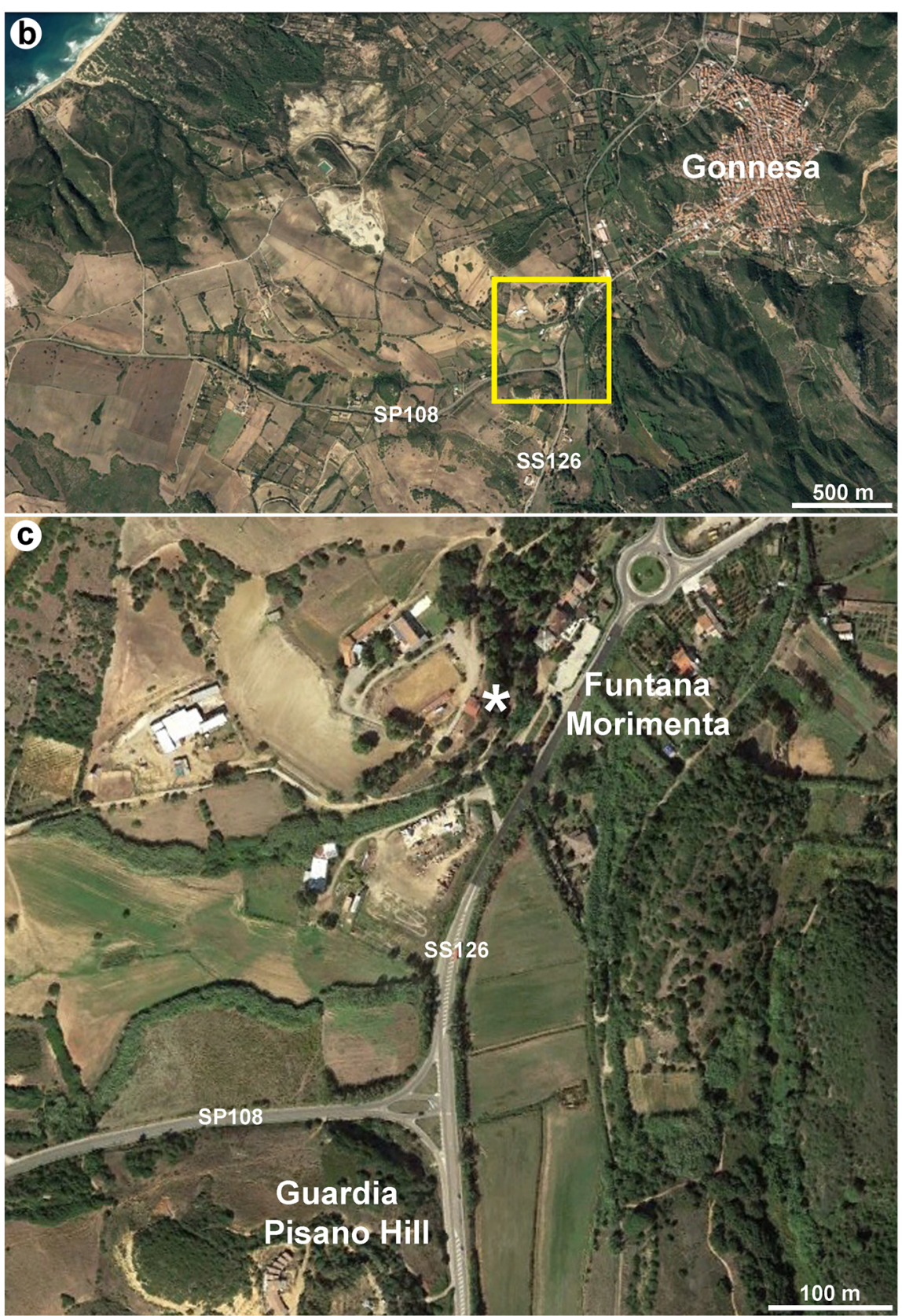

Fig. 1 Geographical location of Funtana Morimenta (Gonnesa, SW Sardinia, Italy). a Location of Sardinia and the Sulcis-Iglesiente sub-region (the red rectangle indicates the Gonnesa area). b General geographical context. c Detailed geographical context 


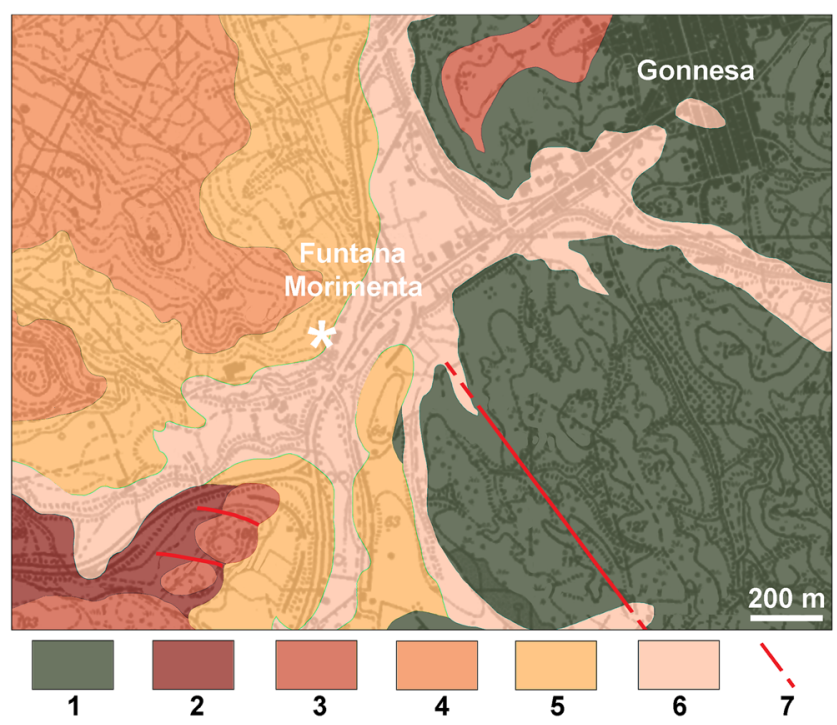

Fig. 2 Geological sketch map of the Gonnesa area: 1 undifferentiated Variscan metamorphic basement (Cambrian-Ordovician), 2 fluvial sandstones and volcaniclastic deposits (Guardia Pisano Fm., Permian), 3 marine and transitional carbonates (Miliolitico Fm., early Ypresian), 4 fluvial conglomerates and sandstones (Cixerri Fm., middle LutetianOligocene), 5 aeolian sandstones and sands (Funtana Morimenta Fm., Middle Pleistocene), 5 alluvial deposits (Holocene), 6 main faults of Sardinia and reconstruction of the palaeoenvironment during the Ice Age (Pillola and Zoboli 2017; Zoboli and Pillola 2018; Pillola et al. 2020). As highlighted by recent investigations, the Funtana Morimenta ichnosite has shown important deterioration because of its susceptibility to weathering. This work aims to indicate a series of efficient requalification actions to protect the area and the ichnofossils, and to offer a great opportunity to promote interest in geosciences and improve awareness of the Italian geo-palaeontological heritage.

\section{Geological and Palaeontological Settings}

The Funtana Morimenta geosite is located in the SulcisIglesiente sub-region (southwestern Sardinia, Italy) about $0.5 \mathrm{~km} \mathrm{~S}-\mathrm{W}$ of the small village of Gonnesa $\left(39^{\circ} 15^{\prime} 25.85^{\prime \prime}\right.$ $\mathrm{N}-8^{\circ} 27^{\prime} 32.30^{\prime \prime} \mathrm{E}$ ), and it is comprised in the Geopark of Sardinia (Parco Geominerario Storico e Ambientale della Sardegna) (Figs. 1 and 2). The site consists of a natural cliff of late Middle Pleistocene aeolian sandstone, with an outcrop of about $10 \mathrm{~m}$ high and $150 \mathrm{~m}$ long, where large-scale cross and low-angle planer stratifications are well-exposed.
Fig. 3 a Natural cliff of late Middle Pleistocene aeolian sandstone of Funtana Morimenta. b Aeolian cross-stratification. c Sandstone cross-sections showing a mammoth footprint and relative deformation of the underlying strata
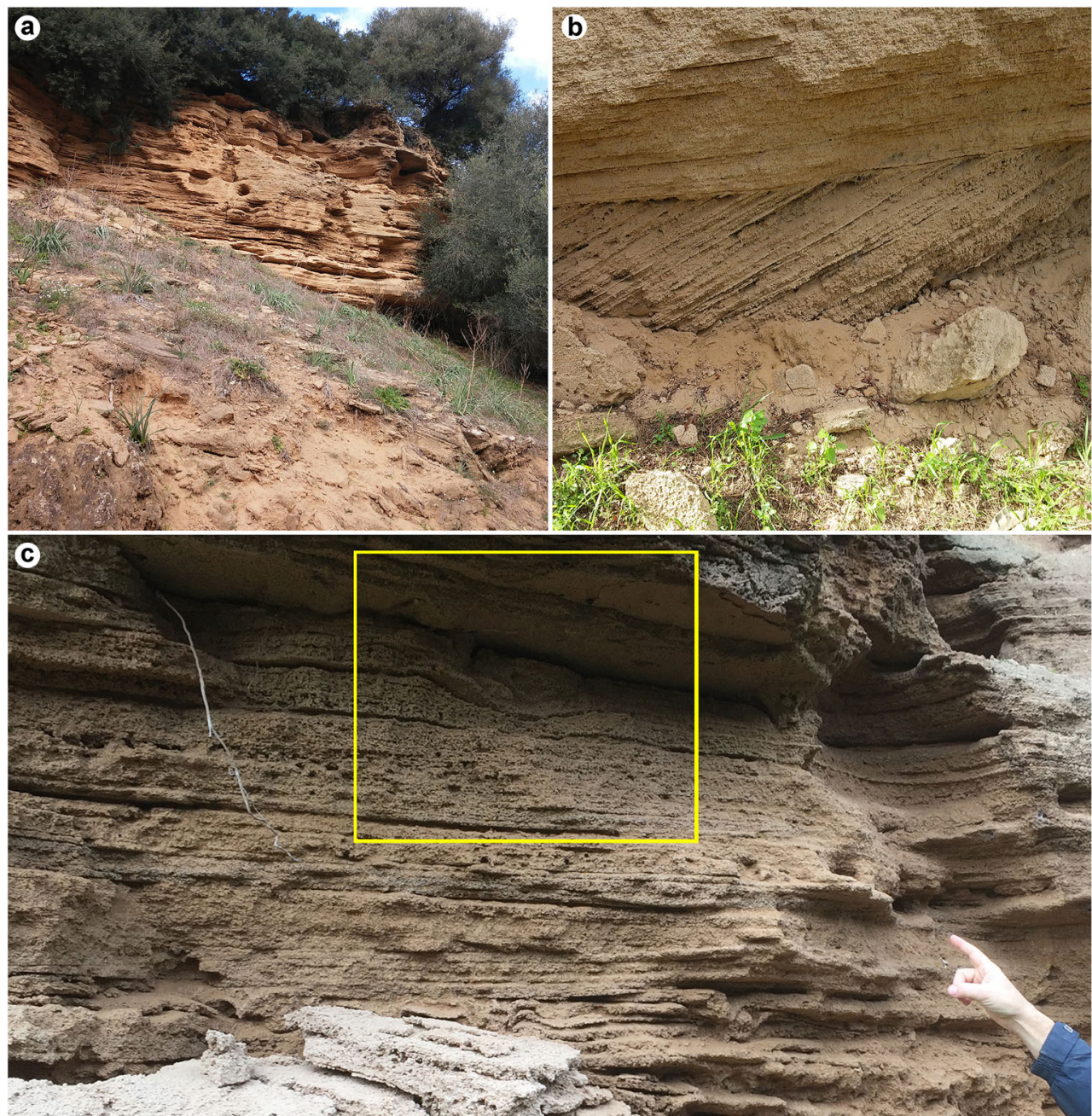
Megacerine deer and mammoth footprints with clear deformations of the underlying laminae are visible in cross-sections along with the natural exposures and concave epireliefs or convex hyporeliefs in large collapsed aeolian sandstone blocks at the base of the cliff (Fig. 3).

Generally, the aeolian deposits cropping out in the western Sardinia were assigned to the Middle to Late Pleistocene age based on the relationships with the interglacial marine deposits of the MIS 5e (Tyrrhenian Stage in the Italian Mediterranean Marine Stages). The geological settings of different aeolian (s.1.) successions in the western coasts of Sardinia show that deposits occur both below and above the marine Tyrrhenian deposits (Pecorini 1954; Lecca and Carboni 2007; Coltorti et al. 2010). The absence of Tyrrhenian marine sediments interposed in the aeolian outcrops of the internal areas represents a problem for a precise chronological context of the continental deposits (Pillola et al. 2020). Concerning the Sulcis-Iglesiente area where the Funtana Morimenta site and other several ichnosites have been identified (Fanelli et al. 2007; Zoboli and Pillola 2018), at least two generations of aeolian deposits are recognized (Orrù and Ulzega 1986). In particular, the oldest of them (Funtana Morimenta Formation) has been attributed to the late Middle Pleistocene based on the relationships with the observed Tyrrhenian marine marker in the near shoreline. The younger aeolian deposits present in several localities of the
Sulcis-Iglesiente area have been attributed to an indefinite Late Pleistocene (Orrù and Ulzega 1986).

The Funtana Morimenta site has been mentioned since the beginning of the nineteenth century by Lamarmora (1857) who reported the first description of the Quaternary aeolian deposits (Fig. 4a, b). However, at the end of the same century, the site became relevant as regards the palaeontology of vertebrates due to the discovery of an incomplete skeleton of a small proboscidean (Figs. 4c, d and 5) (Acconci 1881). The fossil remains, currently regarded as the holotype of Mammuthus lamarmorai (Major 1883), have been found during the construction of a railway and are now housed in different European museums (Fig. 4d) (Major 1883; Comaschi Caria 1965; Zoboli et al. 2018). Comaschi Caria (1965) provided additional data about the proboscidean of Funtana Morimenta and reported that the excavations in the site have been continued for several decades after the first report by Acconci (1881), as confirmed by the dates (1881, 1903, and 1923) reported in the labels associated with the mammoth fossils housed at the Naturhistorisches Museum of Basel (Switzerland). Palombo et al. (2012) revised the location of the mammoth fossil site, demonstrating that the disused railway cited by Acconci (1881) runs at the top of Guardia Pisano hill, a toponym very close to Funtana Morimenta. Accordingly, the authors proposed that the M. lamarmorai remains have been collected in the aeolian deposit still visible
Fig. 4 a Alberto Lamarmora (1789-1863) who first reported the Quaternary aeolian succession of Funtana Morimenta. b The Funtana Morimenta section in the stratigraphical sketch by Lamarmora (1857). c Charles Immanuel Forsyth Major (18431923) who described the dwarf mammoth fossils collected in the Funtana Morimenta area. d Part of the remains of the Sardinian dwarf mammoth Mammuthus lamarmorai, Major's Collection (Naturhistorisches Museum Basel, Switzerland)
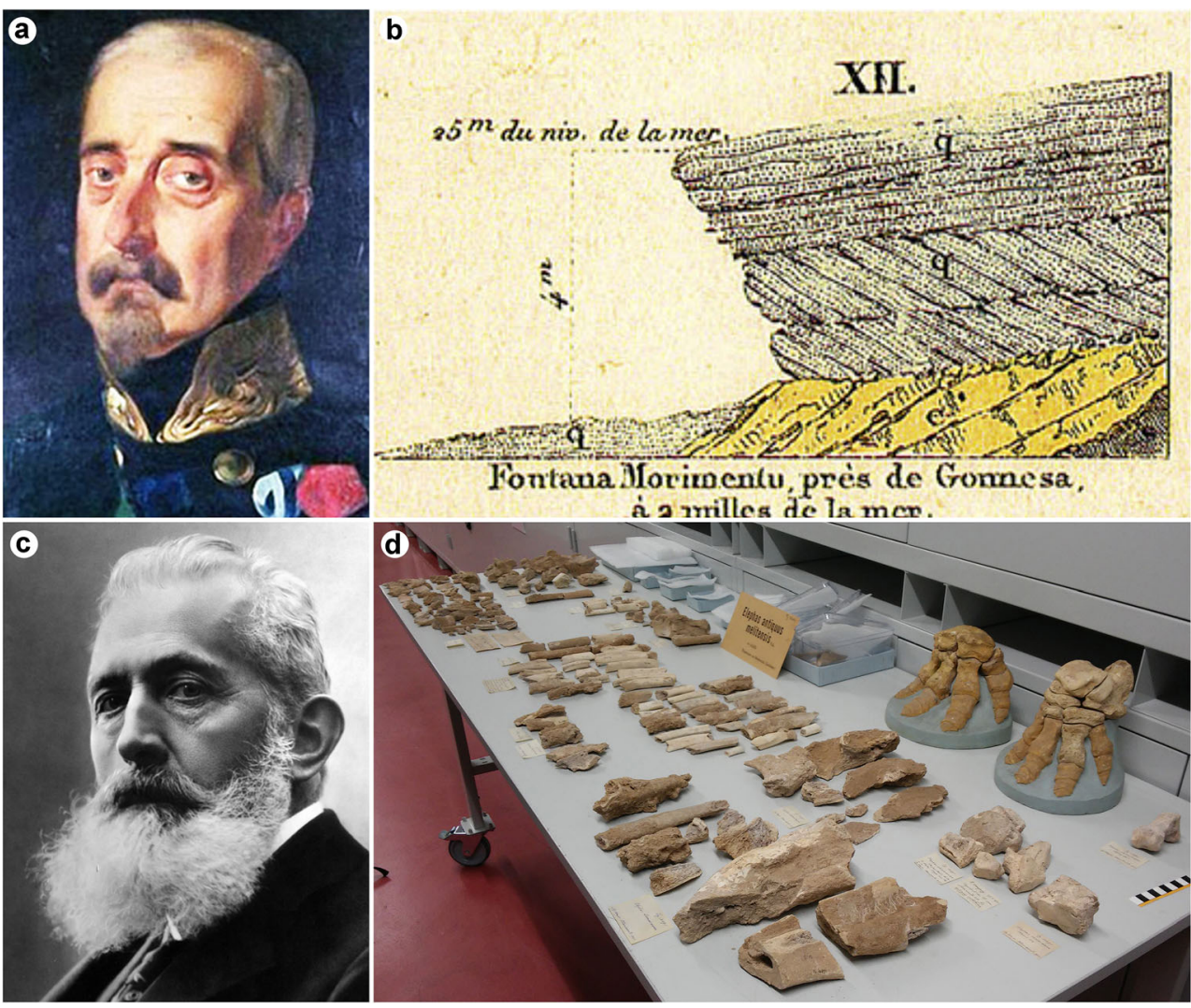


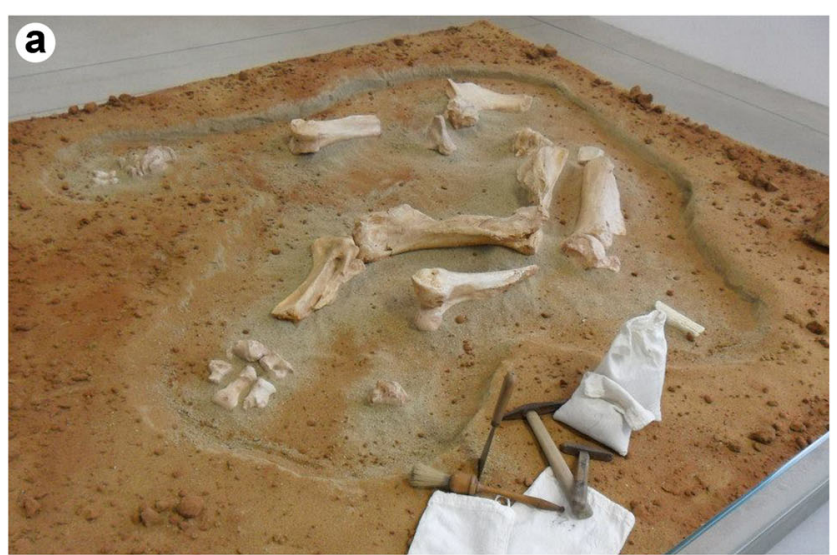

b

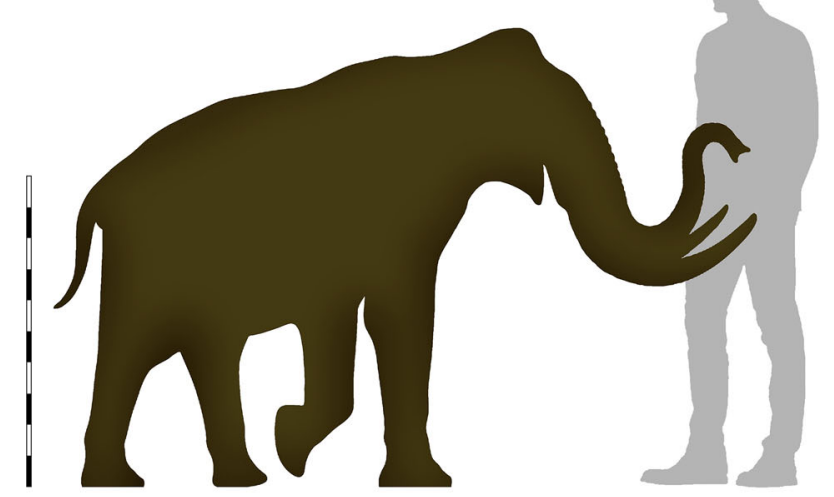

Fig. 5 a Plaster cast of the partial skeleton of Mammuthus lamarmorai collected at the Museo dei Palaeoambienti Sulcitani - E. A. Martel of Carbonia (Sardinia). b Estimated size of $M$. lamarmorai, scale bar corresponds to $1 \mathrm{~m}$

on the slope of Guardia Pisano hill, instead than from the deposits cropping out at Funtana Morimenta, as previously believed.

Recently, a series of studies have highlighted the presence of tracks and trackways left by large mammals. To date, the ichnotaxa reported on the site are Proboscipeda panfamilia McNeil et al. 2007 and Bifidipes isp., respectively left by mammoths and deer (Zoboli and Pillola 2018). Considering shape and size, the proboscidean footprints of Funtana Morimenta have been related to the Sardinian dwarf mammoth M. lamarmorai. It is worth highlighting that these proboscidean footprints represent the first record of mammoth tracks of Italy and potentially the first attributable to a dwarf mammoth in the western Mediterranean Basin (Pillola and Zoboli 2017).

\section{Potential Valorization Actions}

The aeolianites cropping out on the N-NE side of the Guardia Pisano hill, where the remains of the type material of Mammuthus lamarmorai (Major 1883) were found (Palombo et al. 2012), have never been subject to any intervention of protection or enhancement. The site is currently hardly visible from the road crossing between the SS126 and the SP108 roads as it is almost completely covered by shrubs and herbaceous vegetation. There are no traces of the old railway line except for a small bridge over which the railway passed and which now delimits access to private property. In our opinion, this site does not lend itself to an enhancement because of its location.

On the other hand, the Funtana Morimenta aeolianites have been subject to attention due to the presence of an important water source (in the local idiom "Su laccu de s'acqua de sa canna"), a large parking area, and commercial activities. However, the geo-palaeontological site is currently experiencing decay. The vegetation covers part of the aeolian cliff which is almost invisible from the facing parking area (Fig. 6). The deposits also show strong erosional processes with large sandstone blocks collapsed from the cliff or about to detach. Even the dwarf mammoth and megacerine deer tracks, still visible in cross-section, are subject to erosional processes and are irreparably destined to disappear (Fig. 7a, b). Recent surveys have highlighted the state of abandonment of the Funtana Morimenta area and the almost absence of suitable information or any info-point about the geo-palaeontological heritage. The only displayed information is a panel (Fig. 8) placed by private citizens which reports scarce information written in Italian: "In questa località sede dell'antica laveria 'Gonnesa Mining Company of London' fu ritrovato un esemplare di elefante nano" ("In this locality, headquarters of the old mine-washery 'Gonnesa Mining Company of London', a dwarf elephant was found").

As previously highlighted, the ichnosite of Funtana Morimenta lends itself easily to a redevelopment action aimed at its enhancement and fruition (Fig. 9(a-d)). The interventions proposed here are relatively inexpensive and consist of elementary but essential improvements to (a) protect the unique geo-palaeontological heritage, (b) protect the entire area and the potential users, (c) make the geosite more visible from the SS126 road and therefore attract tourists or local people, (d) redevelop the area making it more attractive and functional, and (e) promote interest in geosciences.

The first and fundamental intervention must be finalized to protect the ichnofossils in situ. The natural erosion process on the poorly cemented lithotypes can be arrested using specific consolidating and protective products as acrylic polymers (Sanciu and Zoboli 2018). In addition, a laser-scanning or photogrammetry could be useful to preserve the scientific information and to realize replicas of the more vulnerable tracks that are irreparably destined to disappear.

One of the main problems highlighted during a 2019 inspection is the very poor visibility of the aeolian cliff due to the uncontrolled growth of spontaneous vegetation represented principally by reeds and brambles. The site is not visible 
Fig. 6 The Funtana Morimenta aeolian cliff viewed from the parking area and totally hidden by spontaneous vegetation
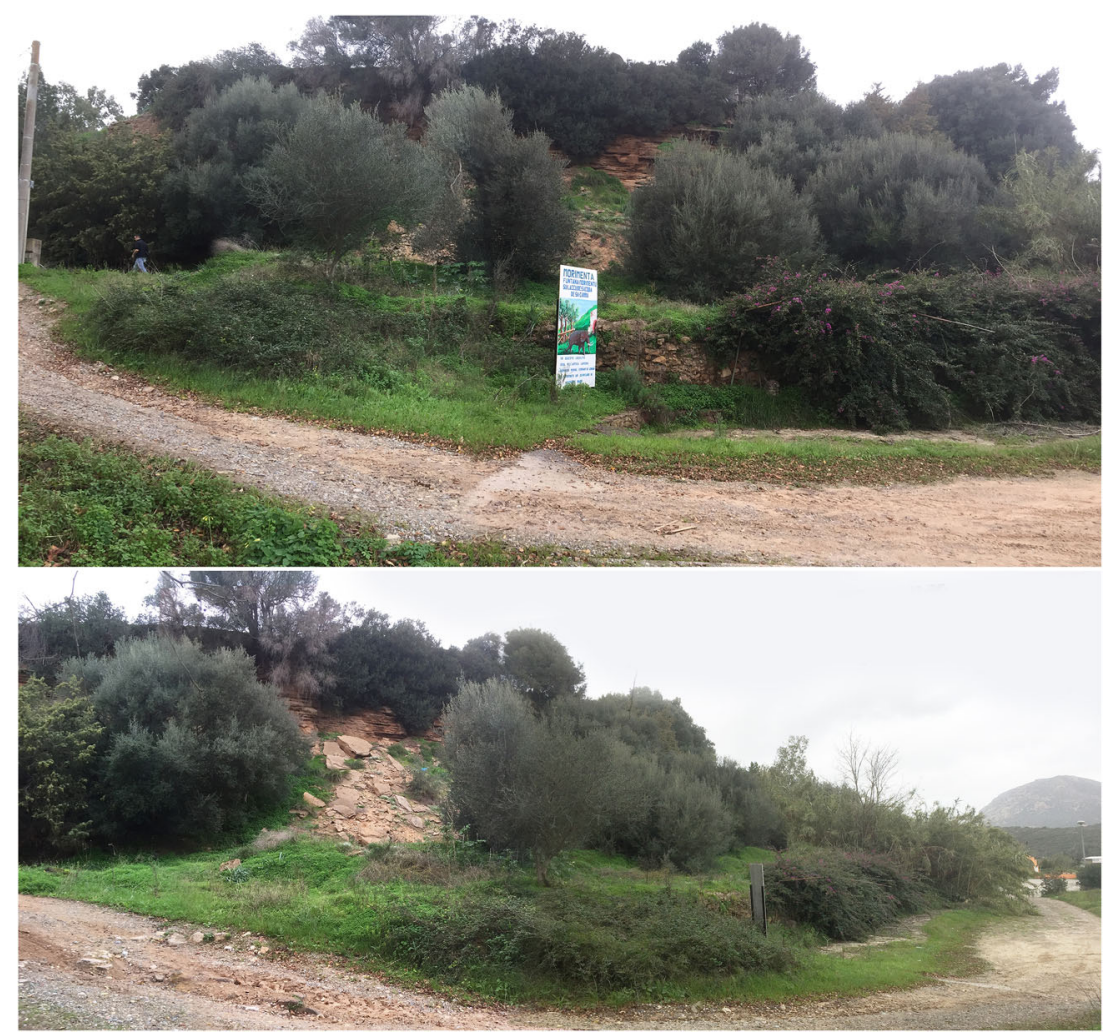
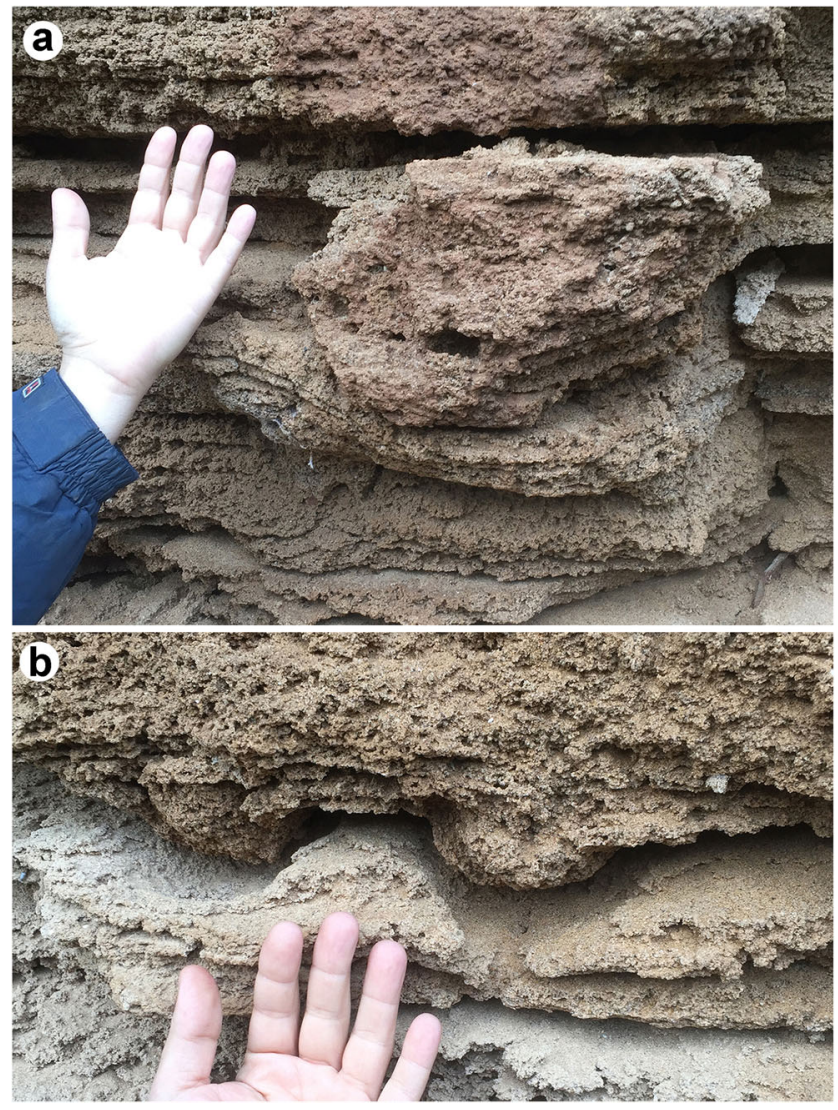

Fig. 7 Current state of preservation of large mammal tracks in crosssection. a Single dwarf mammoth footprint. b Couple of megacerine deer footprints both from the SS126 road and from the parking area of the water source. Therefore, one of the first measures should be the reduction or total eradication of the spontaneous surrounding vegetation.

To consent the protection of the geo-palaeontological heritage and the tourist's safety, another fundamental intervention is to delimit the aeolian cliff (Fig. 9(a)). In order to guarantee a low visual impact, it would be necessary the use of local lithotypes to build low dry stone walls and/or equip the area with wooden fences. Recently, similar solutions have already been chosen in some geosites located in central Sardinia where local administrations have invested in culture and geotourism enhancing their geo-palaeontological heritage (e.g., the geosite "Cava Duidduru" near Genoni in the Sarcidano sub-region and the mega-pillow "Su Corongiu de Fanari” near Masullas in the Marmilla sub-region).

Panels represent the most direct and relatively inexpensive way to disclose information, thorough explanations, artworks, and photographs. For this reason, one of the fundamental objectives of the project will be the installation of appropriate panels giving the visitor scientific and didactic support. Therefore, we suggest a series of panels aimed to explain the history of the geosite and its peculiar geo-palaeontological heritage through drawings and especially palaeoenvironmental reconstructions of the area during the late Middle Pleistocene (Fig. 9(b)). Considering the peculiar fossil biota found in the site, we suggest a series of life-size silhouettes of the dwarf Sardinian mammoth to be placed in 


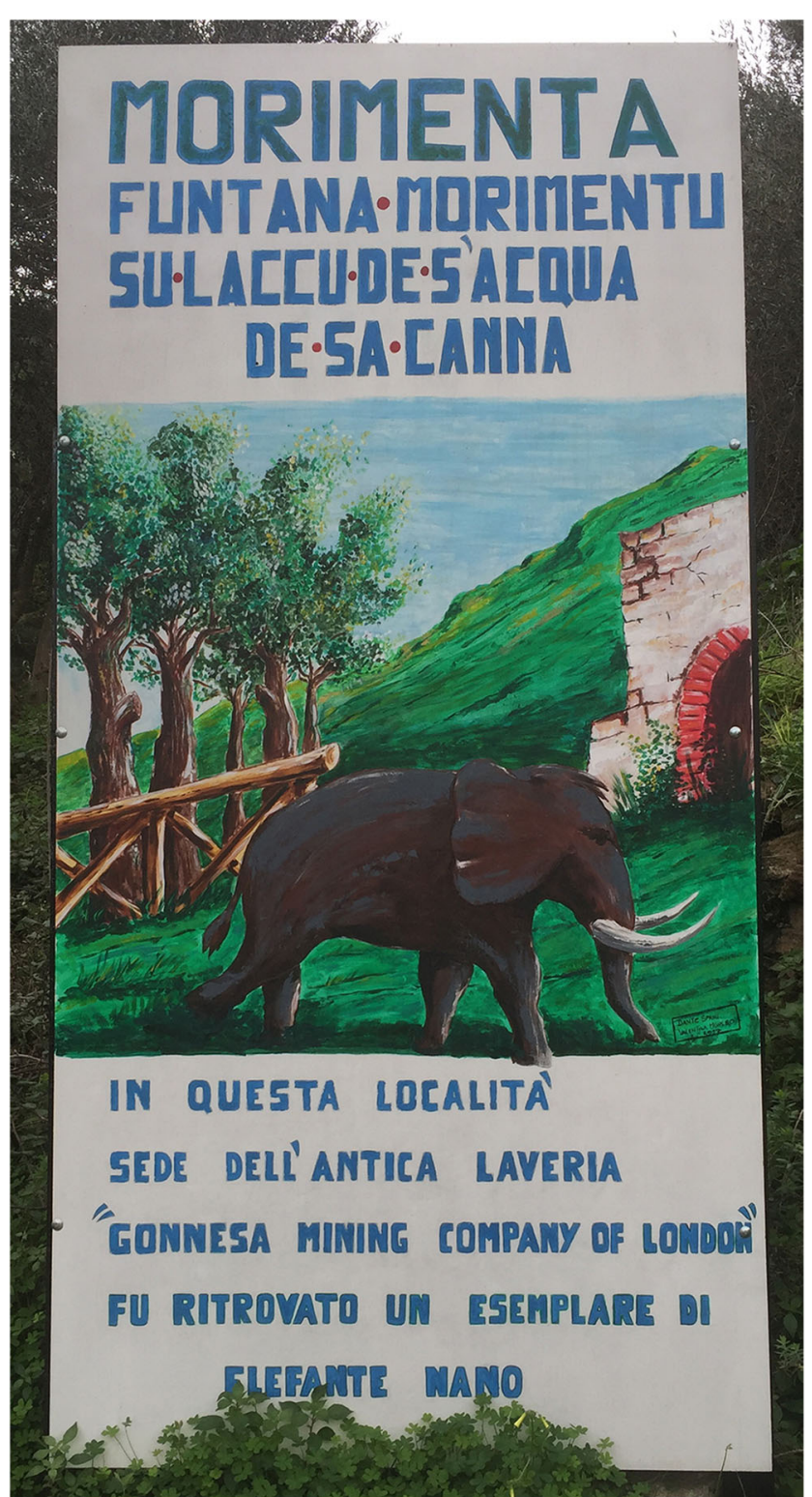

Fig. 8 The only panel on the site of Funtana Morimenta that indicates the presence of a geoheritage

proximity of the site and the SS126 roundabout between Funtana Morimenta and the village of Gonnesa (Fig. 9(c, d)). These silhouettes, achievable using weathering steel, would have the double function to show the real size of the small proboscidate and to indicate the proximity of the geopalaeontological site. Furthermore, it is essential to allocate resources for the maintenance of the geosite and its facilities.

\section{The Relevance of Funtana Morimenta Ichnosite as Palaeontological Heritage}

The geo-palaeontological heritage is an educational resource that can generate aptitudes and attitudes concerning the vulnerability of the Earth systems through the geology, palaeontology, and other branches of geoscience. In recent years, numerous dissemination and promotional initiatives around the world have been developed to increase public heritage interest. In addition, geotourist localities are often used as a relevant socio-economic resource.

The territory of Gonnesa, like much of the Sulcis-Iglesiente sub-region of Sardinia, has a potential value beyond the seaside tourism. The Sulcis-Iglesiente sub-region is very rich in potential geosites distributed in various areas both inland and along the coast which should be protected and enhanced. The area is known for sites of visual beauty, archeological interest, reach mining heritage history that can be properly exploited adding value to the entire territory, and the whole community.

The restoring and dissemination actions here proposed offer a great opportunity to promote interest in geosciences and improve awareness on the importance of geoheritage. The objectives of this work are to spread the knowledge about the late Middle Pleistocene ichnosite of Funtana Morimenta, to emphasize the importance of the educational values of this site, and to expose the need to protect this example of national geo-palaeontological heritage. All actions proposed here would be made possible with a modest investment and could represent a model for similar initiatives in other areas of Sardinia. Therefore, in addition to its outstanding scientific importance, this ichnosite represents a significant geopalaeontological resource that can be developed for geoeducational benefit.

The plan to develop Funtana Morimenta as an educational and geotourist site relies on its survival. However, if no adequate protection is provided, the fossil tracks will quickly deteriorate. Therefore, it is necessary to take urgent measures to protect this geosite. Moreover, the surrounding area offers an outstanding cultural heritage and it would be interesting to publicize this tracksite as well as using this publicity to promote its protection.

\section{Conclusions}

The Sardinian ichnosite herein discussed has great relevance and importance for the geological and palaeontological heritage of Italy and represents an exceptional source of information about the late Middle Pleistocene continental palaeoecosystem of Sardinia. One of the most significant features of the sites is the presence of unique ichnofossils as tracks and trackways left by large mammals of the Ice Age. Among others, this is particularly the case for the still visible proboscidean footprints left by the Sardinian dwarf mammoth Mammuthus lamarmorai (Major 1883), the first attributable to a dwarf mammoth in the western Mediterranean Basin.

It is worth specifying that the site is technically a part of the Geopark of Sardinia; therefore, a rapid intervention by the 


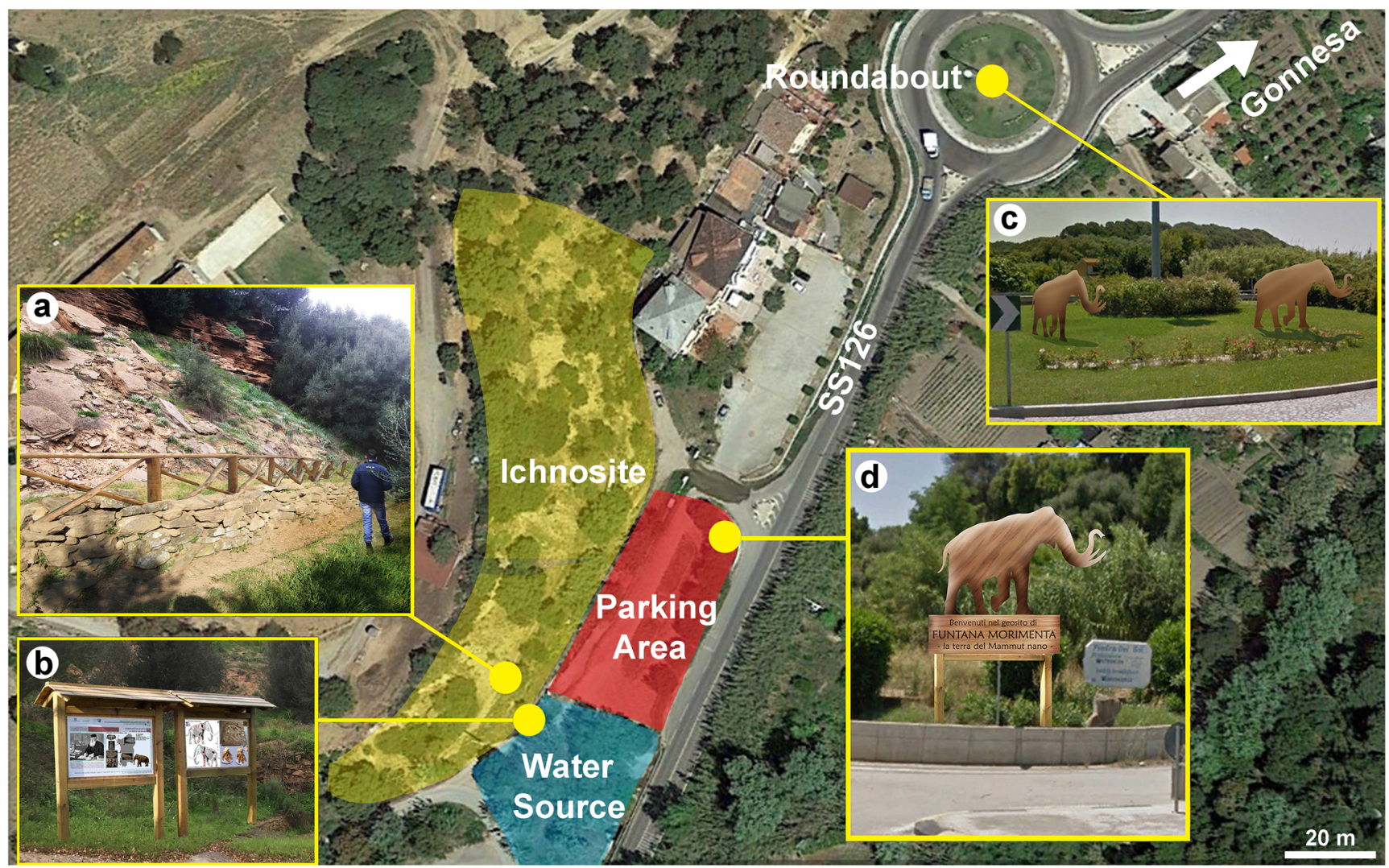

Fig. 9 The Funtana Morimenta area and simulations of the main improvement interventions herein proposed: (a) low dry stone walls and wooden fences at the base of the cliff, (b) panels, (c) life-size silhouettes of the Sardinian dwarf mammoth in the roundabout on the SS126 road, and (d) panel on SS126 to indicate the site competent authorities is solicited so that the entire area and the palaeontological content are protected.

We conclude that the described site, following the proposed low-cost management and restoring actions, can be exposed to public visitation. This would serve the purpose of conservation of geo-palaeontological heritage of Sardinia, assuring the continuation of the scientific research and cultural practices, finally improving the life quality of the local population increasing the geotourism in this Italian region.

Acknowledgements We would like to thank the anonymous reviewer and Mélani Berrocal-Casero (Universidad Complutense de Madrid) for their useful comments that improved the quality of the manuscript and Patrizia Onnis (Environment \& Sustainability Institute, University of Exeter, Penryn, UK) for the grammar revision.

Funding Open access funding provided by Università degli Studi di Cagliari within the CRUI-CARE Agreement. GLP was supported by the Università di Cagliari CAR Project, "Paleobiodiversità: strumento di base in biostratigrafia, in paleoecologia e nella valorizzazione dei beni culturali Geo-Paleontologici." DZ was supported by grants P.O.R. Sardegna F.S.E. 2014-2020 - Asse III "Istruzione e Formazione, Obiettivo Tematico: 10, Obiettivo Specifico: 10.5," Azione dell'accordo di Partenariato: 10.5.12 "Avviso di chiamata per il finanziamento di Progetti di ricerca - Anno 2017."

Open Access This article is licensed under a Creative Commons Attribution 4.0 International License, which permits use, sharing, adaptation, distribution and reproduction in any medium or format, as long as you give appropriate credit to the original author(s) and the source, provide a link to the Creative Commons licence, and indicate if changes were made. The images or other third party material in this article are included in the article's Creative Commons licence, unless indicated otherwise in a credit line to the material. If material is not included in the article's Creative Commons licence and your intended use is not permitted by statutory regulation or exceeds the permitted use, you will need to obtain permission directly from the copyright holder. To view a copy of this licence, visit http://creativecommons.org/licenses/by/4.0/.

\section{References}

Abbazzi L, Angelone C, Arca M, Barisone G, Bedetti C, Delfino M, Kotsakis T, Marcolini F, Palombo MR, Pavia M, Piras P, Rook L, Torre D, Tuveri C, Valli AMF, Wilkens B (2004) Plio-Pleistocene fossil vertebrates of Monte Tuttavista (Orosei, E. Sardinia, Italy), an overview. Rivista Italiana di Paleontologia e Stratigrafia (Research in Paleontology and Stratigraphy) 110:603-628 
Abbazzi L, Delfino M, Gallai G, Trebini L, Rook L (2008) New data on the Vertebrate assemblage of Fiume Santo (North-West Sardinia, Italy), and overview on the late Miocene Tusco-Sardinian palaeobioprovince. Palaeontology 51:425-451

Acconci L (1881) Sopra alcune ossa fossili di Elefante rinvenute nel Quaternario della zona di Morimenta in Sardegna. Processi Verbali Atti Società Toscana di Scienze Naturali 2:266-267

Angelone C, Čermák S, Moncunill-Solé B, Quintana J, Tuveri C, Arca M, Kotsakis T (2018) Systematics and paleobiogeography of Sardolagus obscurus n. gen. n. sp. (Leporidae, Lagomorpha) from the early Pleistocene of Sardinia. J Paleontol 92(3):506-522. https:// doi.org/10.1017/jpa.2017.144

Arzarello P, Finotti F, Galeazzo G, Lanzinger M, Mezzanotte M, Veronese L (2000) Il parco delle piste dei dinosauri di Rovereto: conservazione, valorizzazione e musealizzazione. In: Leonardi G, Mietto P (eds) Dinosauri in Italia, le orme giurassiche dei Lavini di Marco (Trentino) e gli altri resti fossili italiani. Accademia Editoriale, Pisa-Roma, pp 377-390

Audije-Gil J, Barroso-Barcenilla F, Segura M (2018) The Bargalló teaching methodology at the early twentieth century: contributions to palaeontological research and geological heritage. Geoheritage 10: 343-352. https://doi.org/10.1007/s12371-017-0255-y

Berrocal-Casero M, Arribas M, Joaquín Moratalla J (2018) Didactic and divulgative resources of the Middle Triassic vertebrate tracksite of Los Arroturos (Province of Guadalajara, Spain). Geoheritage 10: 375-384. https://doi.org/10.1007/s12371-017-0244-1

Cobos A, Alcalá L (2018) Palaeontological heritage as a resource for promoting geotourism in the rural setting: El Castellar (Teruel, Spain). Geoheritage 10:405-414. https://doi.org/10.1007/s12371017-0248-x

Cobos A, Alcalá L, Royo-Torres R (2020) The Dinosaur Route in El Castellar (Teruel, Spain): palaeontology as a factor of territorial development and scientific education in a sparsely inhabited area. Geoheritage 12:52. https://doi.org/10.1007/s12371-020-00474-3

Coltorti M, Melis E, Patta D (2010) Geomorphology, stratigraphy and facies analysis of some Late Pleistocene and Holocene key deposits along the coast of Sardinia. Quat Int 222:19-35

Comaschi Caria I (1965) L'elefante nano del Quaternario di Gonnesa (Sardegna sud-occidentale). Rendiconti del Seminario della Facoltà di Scienze Università di Cagliari 35:1-11

Dowling RK (2011) Geotourism's global growth. Geoheritage 3:1-1. https://doi.org/10.1007/s12371-010-0024-7

Fanelli F, Palombo MR, Pillola GL, Ibba A (2007) Tracks and trackways of Praemegaceros cazioti (Depéret, 1897, Artiodactyla, Cervidae) in the Pleistocene coastal deposits from Sardinia (Western Mediterranean, Italy). Boll Soc Paleontol Ital 46:47-54

Francischini H, Fernandes MA, Kunzler J, Rodrigues R, Leonardi G, Carvalho IS (2020) The ichnological record of Araraquara Sidewalks: history, conservation, and perspectives from this urban paleontological heritage of southeastern Brazil. Geoheritage 12:50. https://doi.org/10.1007/s12371-020-00472-5

Henriques MH, Pena dos Reis R (2015) Framing the palaeontological heritage within the geological heritage: an integrative vision. Geoheritage 7:249-259. https://doi.org/10.1007/s12371-014-01419

Lamarmora A (1857) Voyage en Sardaigne, III partie, description géologique. Delaforest, Turin

Lecca L, Carboni S (2007) The Tyrrhenian section of San Giovanni di Sinis (Sardinia): stratigraphic record of an irregular single high stand. Rivista Italiana di Paleontologia e Stratigrafia (Research in Paleontology and Stratigraphy) 113:509-523

Major FCJ (1883) Die Tyrrhenis: Studien über geographische Verbreitung von Tieren und Pflanzen im westlich Mittelmeergebiet. Kosmos 13:81-106

Marchetti L, Petti FM, Zoboli D, Pillola GL (2018) Vertebrate and invertebrate trace fossils in the Late Pennsylvanian (Carboniferous) fluvio-lacustrine San Giorgio Basin (south-west Sardinia): remarks on the oldest continental ichnoassociation of Italy. Ichnos 25:94 105. https://doi.org/10.1080/10420940.2017.1337572

Marchetti L, Muscio G, Petti FM, Pillola GL, Zoboli D (2020) The Carboniferous tetrapod ichnoassociation from Italy. In: Romano M and Citton P (Eds) Tetrapod ichnology in Italy: the state of the art. J Mediterr Earth Sci 12:29-37. https://doi.org/10.3304/jmes.2020. 16871

McNeil P, Hills LV, Tolman SM, Kooyman B (2007) Significance of latest Pleistocene tracks, trackways, and trample grounds from southern Alberta, Canada. In: Lucas SG, Spielmann JA and Lockley MG (Eds) Cenozoic Vertebrate Tracks and Traces. New Mexico Museum of Natural History and Science Bulletin 42:209223

Meléndez G (2018) Palaeontological heritage in Spain: from conservation to education. Geoheritage 10:341-342. https://doi.org/10.1007/ s12371-018-0321-0

Melinte-Dobrinescu M, Brustur T, Jipa D, Macaleț R, Ion G, Ion E, Popa A, Stănescu I, Briceag A (2017) The geological and palaeontological heritage of the Buzău Land Geopark (Carpathians, Romania). Geoheritage 9:225-236. https://doi.org/ 10.1007/s12371-016-0202-3

Mennecart B, Zoboli D, Costeur L, Pillola GL (2017) Reassessment of the latest Oligocene ruminant from Sardara, the last non-insular mammal from Sardinia (Italy). Neues Jahrbuch für Paläontologie und Geologie 286(1):97-104. https://doi.org/10.1127/njgpa/2017/ 0688

Mennecart B, Zoboli D, Costeur L, Pillola GL (2019) On the systematic position of the oldest insular ruminant Sardomeryx oschiriensis (Mammalia, Ruminantia) and the early evolution of the Giraffomorpha. J Syst Palaeontol 17(8):691-704. https://doi.org/ 10.1080/14772019.2018.1472145

Orrù P, Ulzega A (1986) Geomorfologia costiera e sottomarina della Baia di Funtanamare (Sardegna sud-occidentale). Geogr Fis Din Quat 9: $59-67$

Palombo MR (2009) Biochronology, paleobiogeography and faunal turnover in western Mediterranean Cenozoic mammals. Integr Zool 4: 367-386

Palombo MR, Valli AMF, Arca M, Tuveri C (2006) A new bovid, Asoletragus gentryi n.gen. et sp., from Monte Tuttavista (Orosei, Eastern Sardinia, Italy). Rivista Italiana di Paleontologia e Stratigrafia (Research in Paleontology and Stratigraphy) 112(3): 459-471. https://doi.org/10.13130/2039-4942/6353

Palombo MR, Ferretti MP, Pillola GL, Chiappini L (2012) A reappraisal of the dwarfed mammoth Mammuthus lamarmorai (Major, 1883) from Gonnesa (south-western Sardinia, Italy). Quat Int 255:158170. https://doi.org/10.1016/j.quaint.2011.05.037

Pecorini G (1954) Le dune fossili della Nurra di Alghero. Rendiconti Accademia dei Lincei 16:735-741

Pillola GL, Zoboli D (2017) Dwarf mammoth footprints from the Pleistocene of Gonnesa (southwestern Sardinia, Italy). Boll Soc Paleontol Ital 56:57-64. https://doi.org/10.4435/BSPI.2017.05

Pillola GL, Palombo MR, Panarello A, Zoboli D (2020) The Pleistocene non-hominid vertebrate ichnofossil record of Italy. In: Romano M \& Citton P (Eds) Tetrapod ichnology in Italy: the state of the art. J Mediterr Earth Sci 12:193-212. https://doi.org/10.3304/jmes.2020. 16872

Sanciu L, Zoboli D (2018) Il Geosito paleontologico "Cava Duidduru" e il Museo P.AR.C. di Genoni: un esempio di ripristino e valorizzazione di un bene geopaleontologico in Sardegna. Museologia Scientifica, nuova serie 12:42-47

Vasconcelos AG, Bittencourt JS, Eliziário NF, Kraemer BM, Auler AS (2020) Stromatolites in caves in Southeastern Brazil and their importance to geoconservation. Geoheritage 12:48. https://doi.org/10. 1007/s12371-020-00469-0 
Zoboli D, Caddeo GA (2016) Articulated skeletons of Prolagus sardus (Mammalia, Lagomorpha) from the Quaternary of Grotta del Campanaccio (Santadi, south-western Sardinia). Boll Soc Paleontol Ital 55(1):81-83. https://doi.org/10.4435/BSPI.2016.08

Zoboli D, Pillola GL (2016) Quaternary mammal fauna from "Surconis", Bolotana (Sardinia, Italy). Boll Soc Paleontol Ital 55:193-203. https://doi.org/10.4435/BSPI.2016.17

Zoboli D, Pillola GL (2017a) Early Miocene insular vertebrates from Laerru (Sardinia, Italy): preliminary note. Rivista Italiana di Paleontologia e Stratigrafia (Research in Paleontology and Stratigraphy) 123(1):149-158. https://doi.org/10.13130/20394942/8073

Zoboli D, Pillola GL (2017b) Upper Pleistocene mammal assemblage from Su Concali Quarry (Samatzai, southern Sardinia, Italy). Rivista Italiana di Paleontologia e Stratigrafia (Research in Paleontology and Stratigraphy) 123(2):243-254. https://doi.org/10. 13130/2039-4942/8371
Zoboli D, Pillola GL (2018) New evidences of mammal tracks from the Pleistocene of Gonnesa area (southwestern Sardinia, Italy). J Mediterr Earth Sci 10:173-175. https://doi.org/10.3304/JMES. 2018.010

Zoboli D, Pillola GL, Rook L (2016) New remains of Macaca majori Azzaroli, 1946 (Primates, Cercopithecidae) from Is Oreris (Fluminimaggiore, southwestern Sardinia). Boll Soc Paleontol Ital 55(3):227-230. https://doi.org/10.4435/BSPI.2016.21

Zoboli D, Pillola GL, Palombo MR (2018) The remains of Mammuthus lamarmorai (Major, 1883) housed in the Naturhistorisches Museum of Basel (Switzerland) and the complete "Skeleton-Puzzle". Boll Soc Paleontol Ital 57:45-57. https://doi.org/10.4435/BSPI.2018.03

Zoboli D, Pala A, Pirellas A, Pillola GL (2019) Pleistocene mammals from Sa Cona Cave (Teulada, south-western Sardinia, Italy). J Mediterr Earth Sci 11:15-29. https://doi.org/10.3304/JMES.2019. 002 